\title{
The Impact of Fiscal Decentralization on Economic Growth in Central and Eastern Europe
}

\author{
By Volodymyr Korotun ${ }^{1}$, Tetiana Kaneva ${ }^{2}$, Anton Drepin ${ }^{3}$, Liudmyla Levaieva ${ }^{4}$, \\ Svitlana Kucherenko ${ }^{5}$
}

\begin{abstract}
In this research, we evaluated the impact of fiscal decentralization on GDP per capita growth. Using the unbalanced panel data, the authors assessed the interconnections between fiscal decentralization - considering its expenditure and revenue aspects as well as tax autonomy - and economic growth for Central and Eastern European countries from 1995 to 2018. In the examined states, the expenditure decentralization exceeded the revenue one. We found out that revenue decentralization and tax autonomy adversely affected economic growth. But expenditure decentralization associated with a positive GDP growth rate. In this paper, we also explored the peculiarities of fiscal decentralization reform. Structural transformations radically reduced the size of the public sector in Central and Eastern Europe, which had a positive effect on the economy. The vital components of local budgets tax revenues are personal income tax and the property taxes. The most effective mechanism for the property tax base's determination arises from the value of the real estate or land.
\end{abstract}

Keywords: fiscal policy, fiscal decentralization, tax autonomy, property taxes, economic growth

\section{Introduction}

Over the past decades, permanent renovations in the quality of institutions intensified growth and strengthened human potential in Central and Eastern European countries. Successful decentralization through the series of structural reforms improved the economic models of those states. Macroeconomic instability, insufficient level of institutional development, the rudiments of a planned economy, and ineffective power redistribution between the different levels of government represented the main threats for the transformations. In some cases, critically limited own revenues contradicted the sub-national governments' intentions to finance budget programs. Conspicuously dependent on the grants from the respective central budgets, some local authorities demonstrated rather pure performance. Meanwhile, consistent financial improvements and innovations ensured the authenticity of the emerging market economies' budget systems. Regarding both institutional features and the regional structure of the economy, the local governments in Central and Eastern Europe hold different combinations of

\footnotetext{
${ }^{1} \mathrm{PhD}$ in Economics, Senior Researcher, First Deputy of Fiscal Policy Research Institute, National State Tax Service University of Ukraine

${ }^{2} \mathrm{PhD}$ in Economics, Associate Professor, Dean of Faculty of Finance and Accounting, Kyiv National University of Trade and Economics, Ukraine

${ }_{3}^{3}$ Postgraduate student, Kyiv National University of Trade and Economics, Ukraine

${ }^{4} \mathrm{PhD}$ in Economics, Associate Professor, Associate Professor in the Department of Economics PereiaslavKhmelnytskyi Hryhorii Skovoroda State Pedagogical University, Ukraine

${ }^{5} \mathrm{PhD}$ in Economics, Associate Professor, Dean of the Faculty of Finance and Humanities, Pereiaslav-

Khmelnytskyi Hryhorii Skovoroda State Pedagogical University, Ukraine
} 
fiscal, administrative, and political powers. Despite the plurality of models, decentralization processes in the countries of that region were quite similar.

There are some reasons to conclude a priori that fiscal decentralization is a beneficial strategy. Firstly, it could increase the local authorities' performance efficiency and improve their capacity to provide high-quality public goods and services due to the advantages of proximity and information accessibility. Secondly, the anticipated increased tax competition and population mobility across fiscal jurisdictions could contribute to the right matching between the territorial communities' preferences and the respective local governments' financial capability. Hence, decentralization theoretically could be a recipe for the public expenditures' optimization despite its strong interconnection with the inherent risks of horizontal fiscal imbalances and macroeconomic instability. Fiscal decentralization commonly proclaimed as the most effective and popular way to overcome the central government's 'grip' on the economy. At the same time, regarding the phenomenon under study, a robust terminological uncertainty occurred. In modern scientific discourse, the terms 'fiscal decentralization' and 'fiscal federalization' are synonyms. However, in the past, the latter could have some political connotations. In some notable cases, the central government's bureaucracy and public services' production geographical deconcentration was identified as fiscal decentralization. As it was mentioned earlier, not only the method of the services delivery (previously centralized) through the regional and local offices matters. The actual essence of decentralization is expressed by the processes of fiscal authority's delegation or devolution to the sub-national level. So, in decentralized financial systems, the elected local governments are empowered to make the decisions on the composition of expenditures and frequently on the structure and the level of revenues as well.

An optimal configuration of the fiscal space means that the local expenditure responsibilities are matching with the endogenous resources, the revenue capacities are corresponding with sub-national elected authorities' political accountability, and the benefit areas are coinciding with the financing ones. The inhabitants of a certain fiscal jurisdiction are interested both in the structure and the quality of the services provided by the respective public authorities. Meanwhile, the above institutions are mandated to gain revenues sufficient to pay for the cost of providing those services. There is no empirical evidence that any territorial unit is capable of producing all the necessary public goods, only utilizing the own respective revenues. In practice, sub-national governments frequently use a wide range of institutional settings (e. g., conditional and unconditional grants), especially in the cases when the services 'spillover' local boundaries.

Moreover, acting as the redistributors or delivers of the services financed by the supreme government, the local authorities provide public welfare and interact both with the specific persons and the community as a whole. Thus, the interests of all the subjects involved should be adequately balanced, and the financial system couldn't be decentralized totally. Therefore, ensuring economic and social justice remains a crucial issue of fiscal decentralization. Some secession risks should continuously be regarded as well. The vast majority of emerging economies in Central and Eastern Europe implemented diverse models of devolution. Burdened in the past by the ambiguous experience of extremely centralized financial planning, those economies showed both advantages and disadvantages of fiscal federalism. Even though decentralization was not 
obligatory directly connected with economic growth and the rapid increase in public welfare, it should be described as the preferable way to transform emerging economies.

\section{Literature Review}

Fiscal decentralization has been considered as a common trend in financial policy throughout the world since the last decades of the $\mathrm{XX}^{\text {th }}$ century. Even though it was a subject of countless specific studies, its composite impact on economic growth remained uncertain. Davoodi \& Zou (1998) empirically investigated the convergencedivergence between revenues and expenditures assignments at sub-national levels of public governance. Despite some common theoretical assumptions that the decentralization's impact on the economic growth rates should be positive, the interconnection between the investigated variables appeared to be slightly negative. Besides, the fiscal system's institutional arrangements should be taken into account. Martinez-Vazquez \& McNab (2003) pointed out that budgetary decentralization could affect economic development, both directly and indirectly. Admitting the fact that empirical data on its direct influence was not satisfactory for general conclusions, the interconnection above remained rather uninterpretable. Meanwhile, a plethora of indirect impact channels (e. g., those that determined economic efficiency, the regional resources' distribution, and macroeconomic stability as well) was disclosed. Due to the methodological issues, no conclusions on the number of dedicated resources in decentralized fiscal systems or the quality of public goods and services produced by different government levels were made. Rodríguez-Pose \& Krøijer (2009), using a panel data approach with dynamic effects, highlighted the interdependency between fiscal decentralization and economic growth in Central and Eastern Europe over the 19902004 period. A significant negative relationship between the examined expenditures decentralization indicators and economic growth was disclosed.

On the contrary, the impact of taxes decentralization was somewhat ambiguous, and in several cases, significantly positive. Finally, the long-run effects varied crucially, depending on a type of devolution undertaken in the financial system. Gemmell, Kneller, \& Sanz (2013) examined the panel data on the OECD member-states, aiming to find the positive interconnection between the decentralization level and the achieved economic growth. Proving the Oates' bypothesis (1972) for the sample, spending decentralization was accomplished by the lower economic growth rates than revenue decentralization. Bird \& Slack (2014) connected decentralization and the governments' intentions to make public finances more efficient, flexible, and responsive. Their study focused on the production of such public services as health care and education. A sound public finance transformation program should combine both revenues and expenditures decentralization measures. Slavinskaite (2017), using the multi-criteria decision-making method, empirically proved that advanced economies of the European Union had a higher degree of fiscal decentralization than emerging market economies. Hence, the local authorities in developed countries had much more power and potential for financial solutions than in developing ones. Martinez-Vazquez, Lago-Peñas \& Sacchi (2017) comprehensively reviewed economic, social, and political dimensions of fiscal decentralization. Pasichnyi (2017) explored the interrelations between public spending 
and GDP growth in different groups of countries and emphasized the directions to increase the positive influence of budget policy on economic development. Generally, the decentralization's overall positive impact was recorded in the majority of cases, if the respective processes had been appropriately designed and implemented. Li (2017) investigated the peculiarities of the tax incentives' adoption in many decentralized financial systems. Even though the above incentives practically led to immediate and essential decline in the revenues from foreign capital, an enormous list of countries chose the respective fiscal option. If the local authorities' accountability was considered as sufficient, decentralization should be regarded as a robust tax competition's trigger, supporting sub-national governments' endogenous financial potential. Meanwhile, fiscal decentralization was not indisputably beneficial, and horizontal tax competition invariably produced inefficiently low rates. Chugunov, Makohon, \& Krykun (2019) determined the impact of fiscal decentralization on economic growth, regarding some necessary institutional conditions of emerging markets and macroeconomic cycles as well.

The paper aims to evaluate the impact of fiscal decentralization on economic growth in Eastern and Central European countries and to assess the peculiarities of this structural reform.

\section{Methods}

In the long-run, economic development is hugely dependent on the compositional structure of public and private incentives (primarily - economic investments, etc.), aimed to encourage the agents' risky and voluntary activity. The government's size generally affects the economic agents' activity, determining its shape and scale as well. Even though the recourses theoretically could be described as the general (rather imperfect than perfect) substitutes, there are lots of evidence that the system's added potential emerges through the combination of the primary economic components. In another way, the economic system's potential $(\mathrm{P}[\mathrm{B}])$ should be described by equation (1), where the emergent potential significantly matters:

$$
P[B]=\sum_{i=1}^{n} b_{i}+\sum_{j=1}^{m} b_{j}^{\prime}
$$

where $b_{i}$ - the potential of the economic systems $i$-th element;

$b_{j}$ - the emergent potential of the $j$-th interconnection between the economic systems' components.

The synergic effect into the national economy is the direct consequence of public and private financial recourses optimal combination, consumption and redistribution, enormously impacted by both social and political factors. Due to the numerous empirical researches, the economic recourses could not be described as the perfect substitutes. Thus, the search for efficient recourses composition and allocation is relevant. Considering the Cobb-Douglas model, economic growth could be described by the function (2):

$$
Y=a * L^{\alpha} * K^{\beta}
$$


where $Y$ - the economic growth expressed by the annual GDP per capita growth rate; $a$ - the technological coefficient;

$L-$ the consumption of (investment into) labor recourses;

$K$ - the consumption of (investment into) capital recourses;

a, $\beta$-the output elasticities of labor and capital, respectively.

According to Barro (1990), the above function should be investigated two separate and mutually interdependent inputs: private capital and public spending. In Eastern and Central Europe, public expenditures are commonly represented by two levels. So, the general government spending is denoted by the equation (3):

$$
g e n-g_{\exp }=c e n-g_{\exp }+l o c-g_{\exp },
$$

where gen_g $g_{\text {exp }}$, cen_g $g_{\text {exp }}, l_{0} c_{\text {exp }}-$ the general, central, and local governments' expenditures, respectively.

If public spending is redistributed between the investments into physical and human capital, the Cobb-Douglas production function can significantly vary. Supposedly, some kind of interconnection between the particular government level's expenditures and revenues exists. Fiscal decentralization was generally intended to optimize the recourse redistribution and to intensify economic development. Meanwhile, the empirical investigation Pasichnyi et al. (2019) have led to rather ambiguous conclusions on the interconnection, as mentioned earlier. In this study, we disclose the main aspects of fiscal decentralization (expenditure, revenue, tax autonomy) regarding the indicators of economic growth in Central and Eastern Europe.

The previous investigations substantiated the necessity of the decentralizations' multiplecriteria assessment. In this particular study, we investigated fiscal decentralization (considering its expenditure, revenue aspects, and tax autonomy), public sector size (given as the percentage to GDP), the investment-to-GDP ratio, and human capital (as the total education as well as research and development expenditures-to-GDP ratio). The last three above indicators were considered as the economic controls.

The revenue decentralization was assessed regarding the below index (4):

$$
R D I=\frac{\operatorname{Re} v_{L G}-G r_{r e c}}{\operatorname{Re} v_{G G}},
$$

where RDI - the revenue decentralization indicator; Rev $v_{L G}$ - the local governments' revenues; Rev $v_{G G}$ - the general governments' revenues; $G r_{r e c}$ - received from other levels of fiscal system inter-government grants and subsidies.

The tax autonomy of the local governments in Central and Eastern Europe was assessed considering the relative tax autonomy index (5):

$$
T A_{r}=\frac{T R_{L G}}{T R_{G G}}
$$

where $T A_{r}$ - the relative tax autonomy indicator; $T R_{L G}, T R_{G G}-$ the local and the general governments' tax revenues, respectively.

The expenditure decentralization was assessed regarding the respective index (6): 


$$
E D I=\frac{\operatorname{Exp}_{L G}}{\operatorname{Exp}_{G G}},
$$

where $T A_{r}-$ the expenditure decentralization indicator; ExpLG, ExpGG - the local and the general governments' expenditures, correspondingly.

Regarding the Cobb-Douglas productive function (2), the estimation technique was represented by ordinary least squares (OLS) with all the variables converted to natural logarithms except for the growth rates of real GDP per capita. Thereby, the overall effect of these factors on economic development is given below (7):

$$
e c-g r_{i, t}=\beta_{0}+\beta_{1} \ln \operatorname{dec}_{i, t}+\beta_{2} \ln \operatorname{contr}_{i, t}+\varepsilon
$$

The summary statistics for the sample is represented in Table 1 (see below):

Table 1: Summary statistics

\begin{tabular}{|l|c|c|c|c|c|}
\hline Variables & Observations & Mean & $\begin{array}{c}\text { Standard } \\
\text { deviation }\end{array}$ & Max & Min \\
\hline GDP growth per capita & 280 & 3.96 & 4.36 & 14.34 & -14.38 \\
\hline ln EDI & 280 & 3.14 & 0.32 & 3.74 & 1.79 \\
\hline ln RDI & 280 & 2.32 & 0.63 & 3.58 & 0.92 \\
\hline ln TA & 280 & 2.39 & 1.03 & 3.86 & 0.25 \\
\hline ln of general public spending (as \% of GDP) & 280 & 3.67 & 0.16 & 4.07 & 3.13 \\
\hline $\begin{array}{l}\text { ln of human capital (educational and R\&D } \\
\text { expenditures as \% of GDP) }\end{array}$ & 280 & 1.78 & 0.23 & 2.31 & 1.16 \\
\hline $\begin{array}{l}\text { ln of investment (gross capital formation as } \\
\% \text { of GDP) }\end{array}$ & 280 & 3.21 & 0.28 & 3.72 & 0.15 \\
\hline
\end{tabular}

Source: the authors' own calculation based on IMF, World Bank and OECD data

We examined the data sample of 13 Central and Eastern European countries, which included Bulgaria, the Czech Republic, Estonia, Hungary, Latvia, Lithuania, Poland, Romania, Slovakia, Slovenia, Ukraine, Belarus, and Moldova over the 1995-2018 period.

\section{Results}

Central and Eastern European countries have a plethora of common characteristics in terms of their economic structure and fiscal space's peculiarities. Over the investigated period, the respective states significantly evolved, modifying their public sectors from highly centralized to decentralized ones. The typical transformation's strategy (enormously dependent on the public institutions' inclusion into the economic agents' routine activities) crucially impacted the traditional economic cycle. Figure 1 represents the interconnection between the national revenue and expenditure decentralization in the region under study.

It was empirically proved that in Central and Eastern Europe, the investigated phenomenon varied significantly. Due to the specific fiscal instrument's parameters (namely a set of conditional and unconditional grants), the investigated decentralization into the sample under study - was disproportional: the expenditure decentralization 
exceeded the revenue decentralization. The fiscal systems of Lithuania and Estonia were the most centralized both in terms of revenues and expenditures, while Belarus was characterized by the highest levels of fiscal federalism. It should be mentioned explicitly that the statistical parameters of the Belarus economy had not to match the respective political liberty's level. There was no explicit connection between the economic development level and the respective degree of fiscal decentralization.

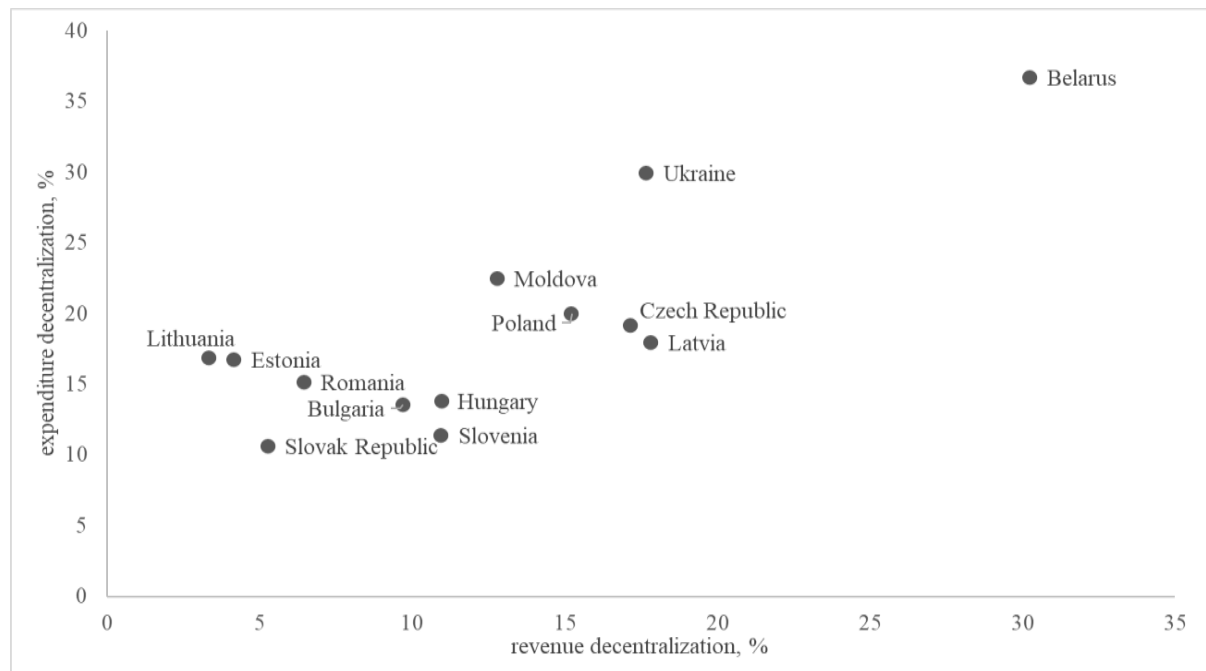

Figure 1. Fiscal decentralization in Central and Eastern Europe countries over 1995-2018 period Source: authors own calculation based on IMF data

Over the investigated period, the conventional financial transformations radically reduced the size of the public sector both in Central and Eastern Europe. The above modernizations were interconnected with the strengthening of the respective territorial units' fiscal capacities. Over the 1995-2018 period, most of the examined territorial communities gained both economic and political powers, sufficient enough to improve the inhabitants' life quality. Even though the GDP per capita growth rates were generally incomparable and hugely dependent on a set of intrinsic factors, the explicit positive overall fiscal decentralization's effect has been proved. The relationships between the levels of economic development and the financial system's specific features remained uncovered. The profound interconnections between economic growth and fiscal decentralization were investigated regarding the model (7). The results are represented in Table 2 (see below).

Table 2: Regressions of fiscal decentralization and controls on economic growth, the sample of Central and Eastern Europe, 1995-2018, unbalanced panel

\begin{tabular}{|l|c|c|c|}
\hline Variables & OLS 1 & OLS 2 & OLS 3 \\
\hline In of public spending (as \% of GDP) & $-6.238^{*}$ & -6.564 & $-6.640^{*}$ \\
& $(1.655)$ & $(1.646)$ & $(1.681)$ \\
\hline In of human capital (educational and R\&D & -1.730 & -1.124 & -1.130 \\
expenditures as \% of GDP) & $(1.160)$ & $(1.098)$ & $(1.117)$ \\
\hline
\end{tabular}




\begin{tabular}{|l|c|c|c|}
\hline Variables & OLS 1 & OLS 2 & OLS 3 \\
\hline In of investment (gross capital formation as \% of GDP) & $\begin{array}{c}4.229^{*} \\
(0.889)\end{array}$ & $\begin{array}{c}4.236^{*} \\
(0.893)\end{array}$ & $\begin{array}{c}4.216^{*} \\
(0.893)\end{array}$ \\
\hline In EDI & $\begin{array}{c}1.074 \\
(0.821)\end{array}$ & - & - \\
\hline $\ln \mathrm{RDI}$ & - & $\begin{array}{c}-0.243 \\
(0.397)\end{array}$ & - \\
\hline $\ln \mathrm{TA}_{\mathrm{r}}$ & - & - & -0.077 \\
\hline $\mathrm{R}^{2}$ & $-0.254)$ \\
$\mathrm{N}$ & 0.254 & 0.250 & 0.249 \\
& 280 & 280 & 280 \\
\hline
\end{tabular}

Notes: The numbers in parentheses are the standard errors of the estimated parameters

'*' denote significance at a 1 percent level

$\mathrm{R}^{2}$ is the adjusted coefficient of determination

Over the 1995-2018 period, the expenditure decentralization's impact on economic development was slightly positive but statistically insignificant. The observed effect was obtained due to the increased efficiency of public control procedures accomplished by the respective local authorities' high transparency and accountability. Both the revenue decentralization and the relative tax autonomy affected the growth processes negatively, while their impacts were statistically insignificant. In all the investigated cases, public spending, and gross capital formation statistically mattered. The public sector size appeared to be negatively interconnected with economic development. Hence, an uncontrolled increase in public spending could slow down the growth processes. In contrast, the general positive dynamics of investment in physical capital boosts economic development; that interrelation appears to be statistically significant. The interconnection between investment in human capital and economic growth is ambiguous. Regarding the sample, it was negative and statistically insignificant. Theoretically, that situation could be improved through the expenditures' structural optimization. In all cases, the adjusted coefficients of determination proved that the examined interconnections were not robust.

Considering Central and Eastern European local budgets' preparation and performance experience, the stochastic relationship between the decentralization level and economic growth happened to be quite controversial and unambiguous for interpretation. The insufficient institutional framework narrowed the regions' financial capacity and reduced the quality of public services offered by the local authorities as well. In contrast, the systematic increase in the redistribution of GDP and GRP through public finances without any improvement in the infrastructure neutrally or even negatively affected the macroeconomic dynamics.

The tax revenues formed the most significant part of the local budget revenues. Regarding two opposite empirical tendencies, the administrative-territorial units' tax autonomy level required an investigation. In Latvia, Poland, the Czech Republic, and Slovenia, the tax autonomy was moderate, while the tax revenues' significance remained low. Meanwhile, in Hungary, Slovakia, and Estonia, the insignificant share of local budgets' tax revenues in the overall structure was accomplished by the essential local government institutions' powers in the field of the tax base and rate determination. 
In several European countries, personal income tax (henceforth - PIT) revenues are historically spitted between the different levels of the respective budget systems. Regarding the significant regional differentiation in wages and employment, that situation is entirely justified. Even in some relatively small countries (e. g. the Baltic States), the unemployment rate - according to the methodology of the International Labor Organization - ranges from 5.0 to $23.0 \%$, and the average wage differs almost significantly, affecting the tax bases. In a number of cases considering emerging economies, the local governments are deprived of the opportunity to influence the tax bases and rates directly. At the same time, there is a direct interrelation between the level of per capita income and the share of PIT revenues redistribution trough the local budgets. Generally, in Central and Eastern Europe, the proportional tax scales are implemented; the tax rates in the above countries are the lowest among the EU member states (in Bulgaria - 10.0\%, in the Czech Republic, Hungary, and Lithuania - $15.0 \%$, in Romania - $16.0 \%$, and in Estonia - $20.0 \%$ ). In those cases, the PIT share in the local budget revenues' structure differs crucially; it is dependent on the number of inhabitants of the territorial community: in some small villages, it equals to $10.0 \%$, in the large cities it reaches $85.0 \%$. In Estonia, the mechanism for splitting the PIT rate is applied; $11.4 \%$ of taxable income is collected to the local budgets. In Poland, the local budgets' PIT revenues depend on the administrative division: $39.34 \%$ is collected to the gmina's (municipality) budget, $10.25 \%$ - to the powiat's (district) budget, and 1.60\% - to the voivodship's (province or state) budget. The similar practice of PIT revenues splitting exists in Slovakia; demography is one of the essential factors in making decisions on establishing the tax revenues' sharing proportions. Thus, $12.7 \%$ are collected to the central state budget, $21.9 \%$ - to the regional (oblast) budgets, and $65.4 \%$ - to the budgets of territorial communities.

In Central and Eastern Europe, dynamic changes in tax legislation in the field of setting the tax rate, determining the tax base as well as the formula for PIT revenues' redistribution between the different levels of the budget system negatively impacted the fiscal forecasting's quality. In contrast, the observed modifications indicate a permanent search for the optimal fiscal space configuration. The tax parameters were justified in the context of changes in the economic situation. That fact crucially increased the cyclicality's impact on the local budgets' revenue formation.

The peculiarities of the enterprises' territorial location and the degree of their business activity in the context of urbanization affect the public authorities' decision to collect the corporate tax to the central budget. In that case, the undesirable interregional differentiation in social and economic development is rationally minimized. Some corporate tax revenues are collected to the local budgets in Slovakia, Lithuania, Bulgaria, and Poland. Moreover, in Poland, the tax sharing ratio depends on the type of administrative-territorial unit (like the situation with PIT). The local budgets of gminas, powiats, and voivodeships receive $6.71 \%, 1.40 \%$, and $14.75 \%$ of the revenues, respectively. In Hungary, the specific local business tax exists. The company's gross profit forms the corresponding tax base, the local governments decide on the tax rate, taking the maximum limit of $2.0 \%$ into account; the control functions are delegated to the National Tax and Customs Administration of Hungary. The local business tax revenues share amounts to $80 \%$ of the total local tax revenues mobilized to the budget. 
Generally, the high level of the regions' tax autonomy is associated with advanced market economies and trustworthy democratic institutions. It achieved through the national taxes' rational splitting between the different levels of the budget system. Fiscally significant local taxes are collected to the respective budgets properly, and the role of intergovernmental grants is reduced. The immobility of the tax base, the corresponding revenues' sustainability despite the economic cycle, and the neutral effect in the context of tax competition indicate the expediency of property taxes' assignment to the local budgets. The citizens can migrate within the country, focused on a wide range of economic criteria for residence in a particular territorial community. The households traditionally form the demand for a set of public goods (e. g., the services connected with the infrastructure development, public health support, education, social protection) proposed by the local authorities. Tiebout (1961) identified the property taxes as an essential source to fund those services, a specific guaranteed and fair mechanism for the public goods' distribution. The robust interconnection between the collected property taxes and the produced public services significantly reduces the populism into the sphere of local governments' decision-making and increases spending efficiency as well. In that case, the taxpayers are becoming more motivated to control the use of mobilized financial resources. Besides, the most effective mechanism for the property tax base's determination arises from the value of the real estate or land. The government imposed a specific framework to avoid all the possible manipulations on the real estate market: the list of credible institutions that have the authority to assess the property value was detailed; some restrictions on mortgage lending were determined, etc.

In the examined sample, the property taxes-to-GDP ratio ranges from $0.30 \%$ to $1.42 \%$; those taxes are commonly assigned to the local budgets. Estonia, Latvia, Poland, and Ukraine form the sub-sample of the countries where $100 \%$ of the property taxes are assigned to the local budgets (Table 3).

Table 3: The property taxes' indicators in Central and Eastern Europe in 2000-2018, average values, $\%$

\begin{tabular}{|l|c|c|c|c|}
\hline $\begin{array}{l}\text { Country } \\
\text { name }\end{array}$ & $\begin{array}{c}\text { The property TR' } \\
\text { share in the local } \\
\text { budgets' TR }\end{array}$ & $\begin{array}{c}\text { The property TR' } \\
\text { collected to the local } \\
\text { budgets share in GDP }\end{array}$ & $\begin{array}{c}\text { The property } \\
\text { taxes-to-GDP } \\
\text { ratio }\end{array}$ & $\begin{array}{c}\text { The property TR' collected } \\
\text { to local budgets share in } \\
\text { the general property TR }\end{array}$ \\
\hline $\begin{array}{l}\text { Czech } \\
\text { Republic }\end{array}$ & 49.80 & 0.19 & 0.45 & 42.22 \\
\hline Estonia & 80.20 & 0.30 & 0.30 & 100.00 \\
\hline Hungary & 21.00 & 0.48 & 0.98 & 48.98 \\
\hline Latvia & 13.57 & 0.72 & 0.96 & 75.00 \\
\hline Lithuania & 80.24 & 0.34 & 0.34 & 100.00 \\
\hline Poland & 35.61 & 1.42 & 1.42 & 100.00 \\
\hline Slovakia & 58.65 & 0.41 & 0.45 & 91.11 \\
\hline Ukraine & 13.04 & 0.80 & 0.80 & 100.00 \\
\hline
\end{tabular}

TR - tax revenues

Source: the authors' own calculation based on the OECD, the Ministry of Finance of Ukraine, and the State Statistics Service of Ukraine data

The property tax shares in the local budgets' tax revenues in Ukraine $(13.04 \%$ ) and 
Latvia $(13.57 \%)$ are almost identical and significantly lower than in the other sampled economies. In Poland, the above indicator is higher by more than 20 percentage points; businesses pay about $80 \%$ of the real estate tax revenues. In 2018, the authorities introduced a specific tax on the commercial real estate (e. g., rented buildings, including office centers, malls, individual shops, and boutiques, the value of which exceeded PLN 10 million). The rental income or the initial value of the taxable asset determined the tax base. A balanced adaptation of the experience mentioned above increases property tax revenues, especially in jurisdictions with a high population density and a significant number of inhabitants.

\section{Discussions}

The authors investigated the decentralization phenomenon taking its multidimensional nature into account. The revenue decentralization negative economic impact could be a consequence of the fact that the local governments collected distorting taxes (e. g., PIT, and the property tax). Even though the expenditure decentralization slightly positively affected economic growth (due to the increased public control and the local authorities' accountability), its influence appeared to be statistically insignificant. Regarding the hypothesis that distortionary taxes reduce economic development and productive local expenditures boost the agents' activity, the optimal composition of the fiscal decentralization's measures both for advanced and emerging market economies could be highlighted in the subsequent scientific investigations. A set of non-economic decentralization impact-factors should be regarded as well.

\section{Conclusions}

In the article, we assessed the fiscal decentralization's impact on economic growth in Central and Eastern European countries over the 1995-2018 period. We found out that the levels of expenditure and revenue decentralization in the region under study varied significantly. Moreover, the financial powers' devolution scale was loosely connected with the other aspects of the investigated phenomenon: political, social, and cultural. Expenditure decentralization positively influenced the growth processes if the local authorities were characterized by high levels of transparency and public accountability. To some extent, revenue decentralization and tax autonomy slowed economic growth down, but their impacts were insignificant as well. Empirical investigations proved the negative interrelation between government spending and economic growth. Hence, the institutional limits for the public expenditures' volume and structure are vital things for advanced and developing countries. Gross capital formation should be considered as one of the essential economic growth determinants. Theoretically, the sub-national governments' fiscal and political autonomy - mutually interconnected with the quality of produced public services - was intended to prompt the regional social and economic development. A high level of tax autonomy is associated with advanced economies and trustworthy democratic institutions.

The main factors which influenced personal income tax revenues' redistribution between the local and central budgets are significant regional economic disproportions, the level 
of per capita income, the number of inhabitants of the territorial community, and demographic factors. The peculiarities of the enterprises' location and the degree of their business activity affect the public authorities' decision to collect the corporate tax to the central budget. One of the crucial fiscal instruments is property taxation. Regarding the investigated countries, Estonia, Latvia, Poland, and Ukraine were characterized by $100 \%$ of the property taxes assignment to the local budgets. The most effective mechanism for the property tax base's determination arises from the value of the real estate or land.

\section{References}

Asatryan, Z., Feld, L. P., \& Geys, B. (2015). Partial fiscal decentralization and sub-national government fiscal discipline: empirical evidence from OECD countries. Public Choice, 163 (3-4), 307-320. DOI: $10.1007 / \mathrm{s} 11127-015-0250-2$

Aslim, E. G., \& Neyapti, B. (2017). Optimal fiscal decentralization: Redistribution and welfare implications. Economic Modelling, 61, 224-234. DOI: 10.1016/i.econmod.2016.12.008.

Bahl, R., \& Bird, R. M. (2018). Fiscal Decentralization and Local Finance in Developing Countries. Edward Elgar Publishing. https://econpapers.repec.org/bookchap/elgeebook/17561.htm

Barro, R. J. (1990). Government spending in a simple model of endogeneous growth. Journal of political economy, 98 (5, Part 2), 103-125. doi:10.1086/261726

Baekgaard, M., \& Kjaergaard, M. (2016). Intergovernmental grants and public expenditures: Evidence from a survey experiment. Local Government Studies, 42(2), 189-207. https://doi.org/10.1080/03003930.2015.1110521.

Benos, N., \& Zotou, S. (2014). Education and economic growth: A meta-regression analysis. World Development, 64, 669-689. DOI: 10.1016/j.worlddev.2014.06.034

Bird, R. M., \& Slack, E. (2014). Local taxes and local expenditures in developing countries: strengthening the Wicksellian connection. Public Administration and Development, 34(5), 359-369. https://doi.org/10.1002/pad.1695.

Chugunov, I., Makohon, V., \& Krykun T. (2019). Budget strategy in the conditions of economic globalization. Problems and Perspectives in Management, 17(3), 101-110. doi: $10.21511 / \mathrm{ppm} .17(3) .2019 .08$

Chugunov, I. \& Pasichnyi, M. (2018). Fiscal stimuli and consolidation in emerging market economies. Investment Management and Financial Innovations, 15(4), 113-122. doi:10.21511/imfi.15(4).2018.09

Davoodi, H., \& Zou, H. F. (1998). Fiscal decentralization and economic growth: A cross-country study. Journal of Urban economics, 43(2), 244-257. https://doi.org/10.1006/juec.1997.2042.

Delgado, F. J, Lago-Peñas, S., \& Mayor M. (2015). On the determinants of local tax rates: new evidence from Spain. Contemporary Economic Policy. 33(2), 351-368. https://doi.org/10.1111/coep.12075.

Gemmell, N., Kneller, R., \& Sanz, I. (2013) Fiscal decentralization and economic growth: spending versus revenue decentralization. Economic Inquiry, 51 (4), 1915-1931. https://doi.org/10.1111/j.14657295.2012.00508.x

Guner, N., Lopez-Daneri, M., \& Ventura, G. (2016). Heterogeneity and Government revenues: Higher taxes at the top? Journal of Monetary Economics, 80, 69-85. https://doi.org/10.1016/j.jmoneco.2016.05.002

$\mathrm{Li}, \mathrm{Q}$. (2016). Fiscal decentralization and tax incentives in the developing world. Review of international political economy, 23(2), 232-260. https://doi.org/10.1080/09692290.2015.1086401.

Martinez-Vazquez, J., \& McNab, R. M. (2003). Fiscal decentralization and economic growth. World development, 31(9), 1597-1616. https://doi.org/10.1016/S0305-750X(03)00109-8

Martinez-Vazquez, J., Lago-Peñas, S., \& Sacchi, A. (2017). The impact of fiscal decentralization: A survey. Journal of Economic Surveys, 31(4), 1095-1129. https://doi.org/10.1111/joes.12182.

Kyriacou, A. P., Muinelo-Gallo, L., \& Roca-Sagalés, O. (2017). Regional inequalities, fiscal decentralization and government quality. Regional Studies, 51(6), 945-957. DOI: 10.1080/00343404.2016.1150992.

Oates, W. E. (1999). An Essay on Fiscal Federalism, Journal of Economic Literature, 37 (3), 1120-1149. DOI: $10.1257 /$ jel.37.3.1120 
Pasichnyi, M. (2017). Empirical study of the fiscal policy impact on economic growth. Problems and Perspectives in Management, 15(3), 316-322. http:// dx.doi.org/10.21511/ppm.15(3-2).2017.01

Pasichnyi, M., Kaneva, T., Ruban, M., Nepytaliuk, A. (2019). The impact of fiscal decentralization on economic development. Investment Management and Financial Innovations, 16 (3), 29-39. https://doi.org/10.21511/imfi.16(3).2019.04

Rodriguez-Pose, A., \& Krøijer, A. (2009). Fiscal Decentralization and Economic Growth in Central and Eastern Europe, Growth and Change, 40, 387-417. https://doi.org/10.1111/j.14682257.2009.00488.x

Sacchi, A., \& Salotti, S. (2017). The influence of decentralized taxes and intergovernmental grants on local $\begin{array}{llll}\text { spending } & \text { volatility. }\end{array}$ https://doi.org/10.1080/00343404.2015.1111512.

Slavinskaite, N. (2017). Fiscal decentralization in Central and Eastern Europe. Global Journal of Business, Economics and Management: Current Issues, 7(1), 69-79. https://doi.org/10.18844/gjbem.v7i1.1236.

Tiebout, C. M. (1961). An economic theory of fiscal decentralization. NBER, public finances, needs, sources, and utilization. Princeton Univ. Press. 79-96. http://www.nber.org/chapters/c2273.pdf. 